\title{
Giant Cell Tumor of Rib Arising Anteriorly as a Large Inframammary Mass: A Case Report and Review of the Literature
}

\author{
Amit Sharma ${ }^{1}$ and Amy E. Armstrong ${ }^{2}$ \\ ${ }^{1}$ Division of Transplantation Surgery, Department of Surgery, Virginia Commonwealth University, \\ P.O. Box 980057, Richmond, VA 23298, USA \\ ${ }^{2}$ Virginia Commonwealth University School of Medicine, 1101 E. Marshall Street, Richmond, VA 23298, USA
}

Correspondence should be addressed to Amit Sharma, asharma@mcvh-vcu.edu

Received 9 July 2012; Accepted 8 November 2012

Academic Editor: Jeffrey C. Wang

Copyright ( $) 2012$ A. Sharma and A. E. Armstrong. This is an open access article distributed under the Creative Commons Attribution License, which permits unrestricted use, distribution, and reproduction in any medium, provided the original work is properly cited.

\begin{abstract}
Introduction. Giant cell tumor of the bone is a rare benign lesion that infrequently affects the ribs, and if present, is usually located posteriorly. The rarity of this tumor poses diagnostic and therapeutic problems for physicians, especially when it is located in the anterior arc of the rib in close proximity to the breasts in female patients. Case Presentation. We report the case of a 32-year-old Asian female with a giant cell tumor of her anterior rib, presenting as a large inframammary mass. Computed tomography showed a tumor arising from the 7 th rib anteriorly with marginal sclerosis, cortical destruction, and a soft tissue mass. She was treated with surgical resection, and the defect was reconstructed primarily. The surgical specimen measured $28.0 \times 24.0 \mathrm{~cm}$. The microscopic examination showed a large number of multinucleate giant cells scattered over the parenchyma. Patient recovered uneventfully and continues to be recurrence-free six years after surgical resection. Conclusion. We report the largest known case of giant cell tumor arising from the anterior aspect of a rib. We recommend including giant cell tumor in the differential diagnosis of chest wall masses especially in female patients, regardless of the size on clinical examination.
\end{abstract}

\section{Introduction}

Giant cell tumors (GCTs) of bone usually arise in the epiphyseal region of the limbs, and their occurrence in the ribs is unusual [1]. These are usually found posteriorly in the ribs (epiphysis of head and tubercle), and their presentation anteriorly is very rare [2]. Giant cell tumors of the anterior rib in close proximity to the breasts may pose diagnostic and therapeutic problems [3], which prompted us to report this unusual case.

\section{Case Presentation}

MK, a 32-year-old Asian female, was admitted to our surgical unit with the chief complaint of a slowly enlarging mass just below her left breast for past 4 years. The only associated symptom was mild occasional pain of recent onset. Clinically, the lump was approximately $20.0 \times 15.0 \mathrm{~cm}$, hard in consistency, mildly tender, and located anteriorly below the left inframammary fold (Figure 1). The margins were indistinct, and the surface was smooth with tense, patchily erythematous overlying skin.

Chest and abdominal radiographs showed a radiolucent shadow in the left lower chest region. Computed tomography of the chest (Figure 2) showed a tumor arising from the 7th rib anteriorly with marginal sclerosis, cortical destruction, and a soft tissue mass. The patient was investigated to rule out hyperparathyroidism.

The tumor was excised along with the rib above and below and a length well past the tumor margin. The defect was reconstructed primarily, and the patient made an uneventful recovery. Histopathology reported a large lobular mass enclosing the rib and measuring $28.0 \times 24.0 \mathrm{~cm}$ (Figure 3). Cut section showed areas of necrosis, hemorrhage, and a gritty feel.

Microscopic examination revealed a large number of multinucleate giant cells scattered over the parenchyma (Figure 4). The stroma contained vesicular plump spindle 


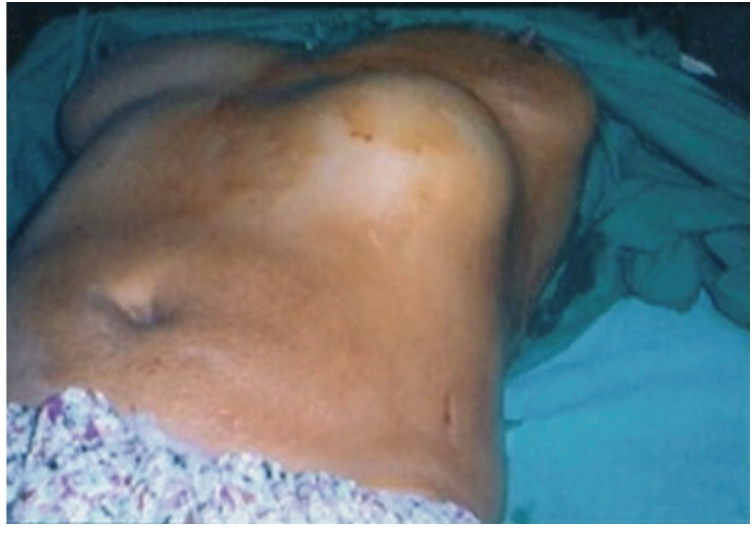

(a)

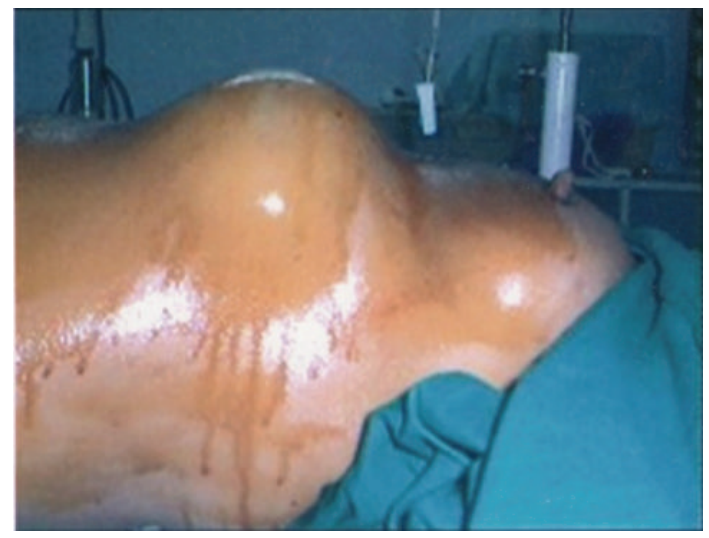

(b)

Figure 1: Clinical appearance of the left inframammary giant cell tumor. Picture shows the left inframammary mass just prior to surgical resection (after prepping with betadine solution) in frontal (a) and lateral (b) view.

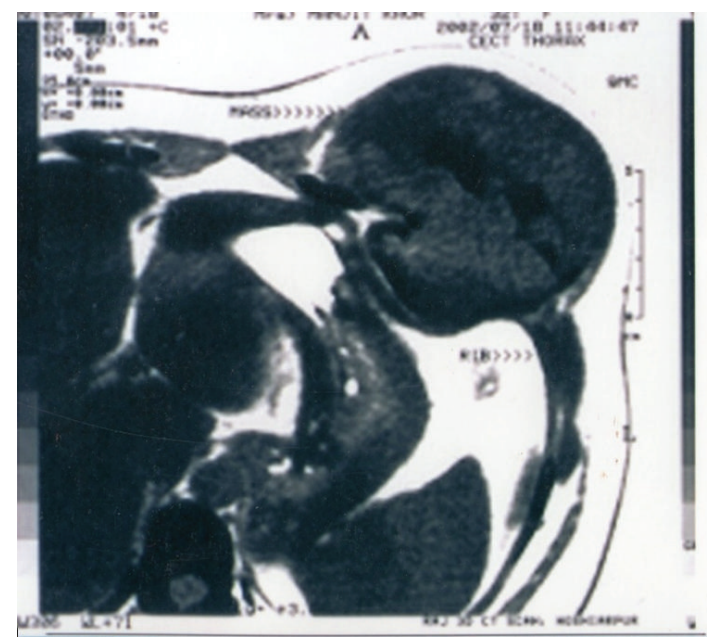

Figure 2: Giant cell tumor on CT scan of the chest. Computed tomography of the chest showing a large soft tissue mass arising anteriorly from the 7 th rib, causing cortical destruction.

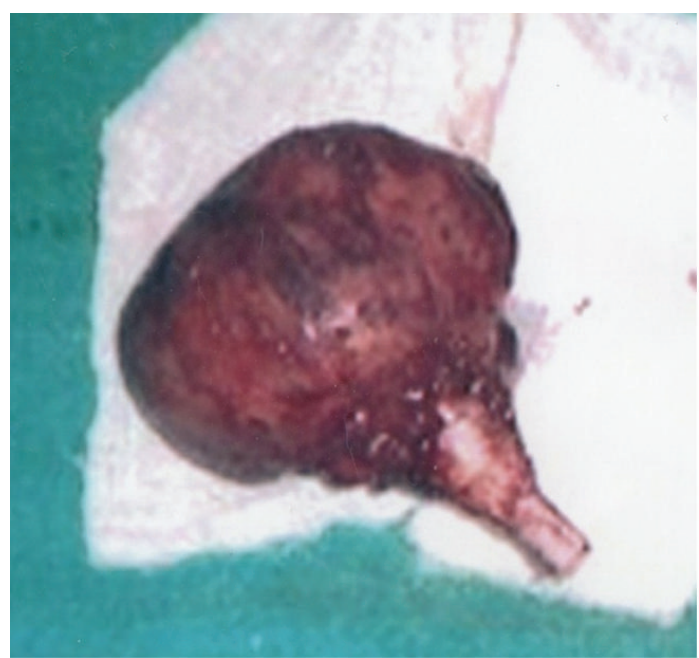

FIGURE 3: Gross specimen after surgical resection. Specimen showing giant cell tumor measuring $28.0 \times 24.0 \mathrm{~cm}$ with an excised portion of the 7 th rib.

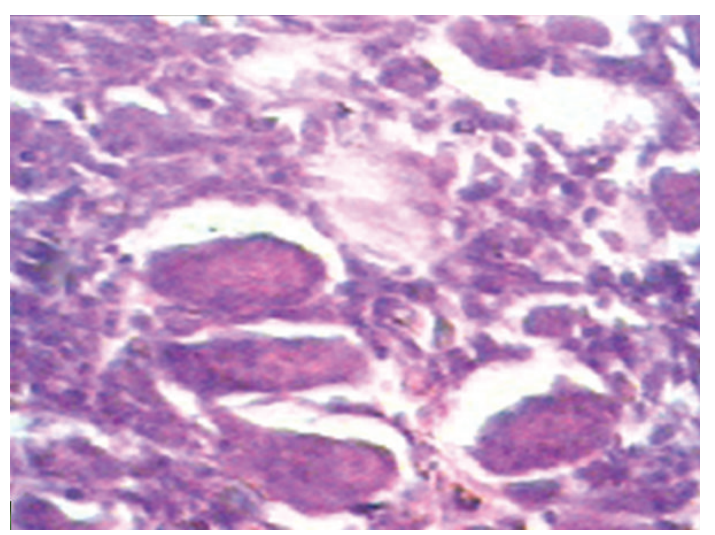

FIGURE 4: Histopathology of giant cell tumor. Microscopic examination with hematoxylin and eosin staining showing large number of multinucleate giant cells scattered over parenchyma with spindleshaped mononuclear stromal cells (magnification $\times 100$ ).

cells with nuclei. There were large areas of hemorrhage and necrosis. A final impression was made of a grade III giant cell tumor of the rib. The patient remains recurrence free 6 years after tumor excision.

\section{Discussion}

Giant cell tumors of the bone account for $5 \%$ of all primary bone tumors [4]. Most (85\%) occur in the long bones, and approximately $50 \%$ are found around the knee joint. Many large series have reported an incidence of around $1 \%$ in the ribs; after reviewing 15 cases, Gupta and Mittal show that most of these involved the posterior aspect of the rib [2]. Microscopically, the two basic components of benign GCTs are stroma and multinucleated giant cells; the stromal cells are mononuclear and may be spindle shaped, ovoid, or round, while the multinucleated giant cells may be so large that the numerous nuclei are almost uncountable. 
TABLE 1: Published cases of giant cell tumors arising from anterior arc of the rib.

\begin{tabular}{lcc}
\hline Author & Location & $\begin{array}{c}\text { Surgical specimen } \\
\text { size }(\mathrm{cm})^{\mathrm{a}}\end{array}$ \\
\hline Riddle et al. [8] & 5th anterior & $5.0 \times 5.0 \times 4.5$ \\
Sakao et al. [9] & 5th (anterior?) & $5.8 \times 5.2$ \\
Sakao et al. [9] & 2nd anterior & $6.0 \times 3.5$ \\
Tavecchio et al. [10] & 11th & $7.0 \times 6.0$ \\
Shin et al. [11] & 2nd anterior & $8.0 \times 6.5 \times 6.0$ \\
Sakao et al. [9] & 2nd anterior & $9.0 \times 7.0 \times 5.0$ \\
Al-Otaibi et al. [12] & 9th anterior & $9.5 \times 6.5 \times 3.0$ \\
Sakao et al. [9] & 4th anterior & $10.0 \times 7.0 \times 5.0$ \\
Sakao et al. [9] & 3rd anterior & $11.0 \times 12.0 \times 13.0$ \\
Dehghan et al. [4] & 4th anterior & $12.5 \times 10.5 \times 5.7$ \\
Briccoli et al. [13] & 9th anterior/posterior & $13.0 \times 11.0 \times 2.5$ \\
Sakao et al. [9] & 4th anterior & $15.0 \times 7.5 \times 5.5$ \\
Cordeiro et al. [14] & 4th and 5th anterior & $25.0 \times 17.0$ \\
\hline
\end{tabular}

${ }^{a}$ In our case report the giant cell tumor originated from the anterior aspect of the left 7th rib. The excised specimen measured $28.0 \mathrm{~cm} \times 24.0 \mathrm{~cm}$.

The frequency of multinucleated giant cells is variable and most likely dependent on stromal pattern [5]. Variants of GCTs include chondroblastoma, chondromyxoid fibroma, aneurysmal bone cyst, and "brown" tumor of hyperparathyroidism [6]. When differentiating GCTs of rib from simple bone cyst Oschner described that the latter are more likely to be formed in the anterior part of the ribs, whereas GCT are mostly located posteriorly in the epiphysis of bone (i.e., the head and tubercle of ribs) [7]. Only 3\% of GCTs develops in the immature skeletons which distinguishes these patients from those with aneurysmal bone cysts, in whom the tumor maximally occurs prior to epiphyseal fusion [6].

Giant cell tumors are aggressive tumors and present with the signs and symptoms of pain, swelling, and limitation of motion about a joint. Hutter et al. report that patients experienced symptoms for an average of 10 months prior to first treatment of benign GCT [5]. However, our patient noted a slowly growing inframammary mass over a period of 3 to 4 years, and the occasional pain began near her time of presentation. This delayed presentation probably contributed to the extremely large tumor size found at the time of surgical resection. While multiple cases of GCT originating from the rib have been reported, the twodimensional span of $28.0 \times 24.0 \mathrm{~cm}$ resected in our patient appears to be the largest to date (Table 1) $[4,8-14]$.

Current methods available to treat GCT include curettage with or without the use of alcohol, liquid nitrogen, phenol or methylmacrylate or bone graft, and complete surgical resection of the affected segment of bone [8]. Excision is desirable as $10 \%$ of GCTs in ribs undergo malignant transformation [7], while radiation therapy is not recommended as most of malignant transformations are related to previous radiation therapy [4]. Thus en bloc excision is an appropriate treatment, and disease-free survival is directly proportional to negative resection margin [15]. Hutter et al. report that most recurrences $(81 \%)$ appear in less than 2 years, and almost all have been manifested by 4 years. Thus at least 5 years of close followup are recommended. However, it has been reported that the course of a benign giant cell tumor undergoing malignant transformation may take longer than 5 years [5].

\section{Conclusion}

In conclusion, ribs are a rare site for giant cell tumor and when present most of these tumors are located posteriorly near the epiphysis of the rib. We report the largest known case of giant cell tumor located on the anterior aspect of rib that was successfully managed with wide excision and primary repair of the chest wall defect without any recurrence.

\section{Consent}

Written informed consent was obtained from the patient for publication of this case report and accompanying images. A copy of the written consent is available for review by the editor-in-chief of this journal.

\section{Conflict of Interests}

The authors declare that they have no conflict of interests.

\section{Authors' Contribution}

A. Sharma conceived, critically revised, wrote, and edited the paper. A. Armstrong collected data, reviewed the literature, and wrote the paper. All authors read and approved the final paper.

\section{References}

[1] M. Kito, T. Umeda, and T. Koyama, "Two giant cell tumors arising from the ribs: two case reports," International Journal of Clinical Oncology, vol. 4, no. 2, pp. 107-111, 1999.

[2] V. Gupta and R. Mittal, "Giant cell tumor of rib-rare location on the anterior aspect," Archives of Orthopaedic and Trauma Surgery, vol. 120, no. 3-4, pp. 231-232, 2000.

[3] M. O. Tachdjian, "Bone tumors," in Pediatric Orthopaedics, M. O. Tachdjian, Ed., pp. 115-117, Saunders, Philadelphia, Pa, USA, 1990.

[4] A. Dehghan, A. H. Moaddab, M. Eskandarlou, and A. Moeeni, "Anterior chest wall giant cell tumor," General Thoracic and Cardiovascular Surgery, vol. 58, no. 1, pp. 39-41, 2010.

[5] R. V. Hutter, J. N. Worcester Jr., K. C. Francis, F. W. Foote Jr., and F. W. Stewart, "Benign and malignant giant cell tumors of bone. A clinicopathological analysis of the natural history of the disease," Cancer, vol. 15, pp. 653-690, 1962.

[6] I. Watt, "Tumors and tumor-like conditions of bone," in Textbook of Radiology and Medical Imaging, D. Sutton, Ed., vol. 1, pp. 163-164, Churchill Livingstone, Philadelphia, Pa, USA, 1992.

[7] A. Oschner Sr., A. Oschner Jr. et al., "Tumors of the thoracic wall," in Diagnosis and Treatment of Tumors of the Chest, D. M. Spain, S. M. Farber, E. Mayer et al., Eds., Grune Stratton, New York, NY, USA, 1960.

[8] N. D. Riddle, H. Yamauchi, J. T. Caracciolo, D. Cheong, N. Khakpour, and M. M. Bui, "Giant cell tumor of the anterior 
rib masquerading as a breast mass: a case report and review of current literature," Cases Journal, vol. 3, no. 2, article 51, 2010.

[9] Y. Sakao, T. Sakuragi, Y. Takeda, M. Natsuaki, and T. Itoh, "Giant cell tumor of the rib," Japanese Journal of Thoracic and Cardiovascular Surgery, vol. 51, no. 10, pp. 537-540, 2003.

[10] L. Tavecchio, S. Radaelli, G. Pelosi, F. Leo, and U. Pastorino, "Unusual giant cell tumor of a floating rib: a case report," in Tumori, vol. 97, no. 5, pp. 34e-35e, 2011.

[11] J. S. Shin, I. S. Lee, A. Kim, and B. H. Kim, "Giant cell tumor originating from the anterior arc of the rib," Journal of Korean Medical Science, vol. 17, no. 6, pp. 849-851, 2002.

[12] M. L. Al-Otaibi, F. F. Al-Jassir, and M. H. Isler, "Giant cell tumor of the rib," Saudi Medical Journal, vol. 27, no. 8, p. 1248, 2006.

[13] A. Briccoli, C. Malaguti, C. Iannetti, M. Rocca, and F. Bertoni, "Giant cell tumor of the rib," Skeletal Radiology, vol. 32, no. 2, pp. 107-110, 2003.

[14] S. Z. D. B. Cordeiro, P. D. B. Cordeiro, A. M. C. Sousa, D. C. Lannes, and G. S. D. M. Pierro, "Giant cell tumor of the rib occupying the entire hemithorax," Jornal Brasileiro de Pneumologia, vol. 34, no. 3, pp. 185-188, 2008.

[15] R. M. King, P. C. Pairolero, V. F. Trastek, J. M. Piehler, W. S. Payne, and P. E. Bernatz, "Primary chest wall tumors: factors affecting survival," Annals of Thoracic Surgery, vol. 41, no. 6, pp. 597-601, 1986. 


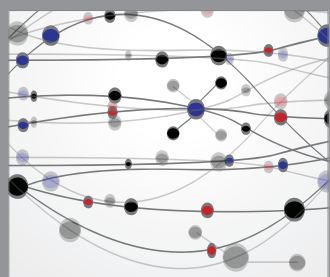

The Scientific World Journal
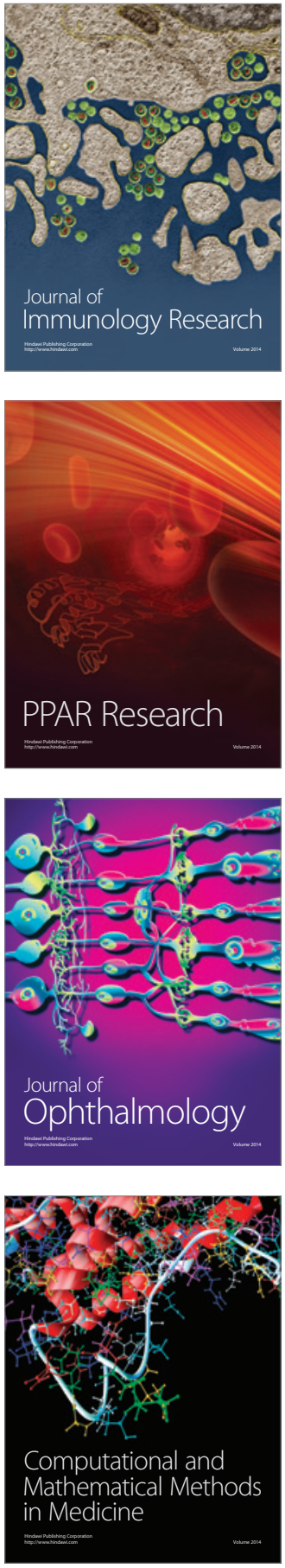

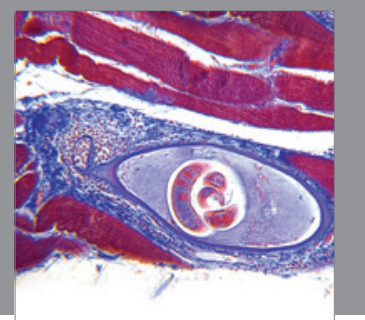

Gastroenterology

Research and Practice
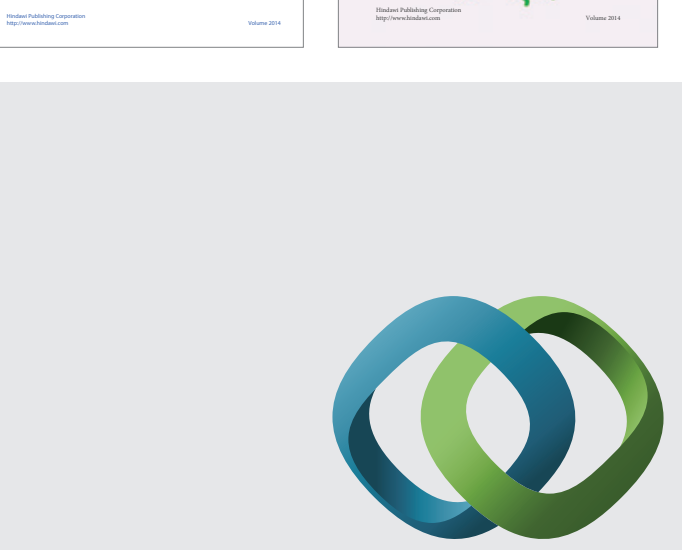

\section{Hindawi}

Submit your manuscripts at

http://www.hindawi.com
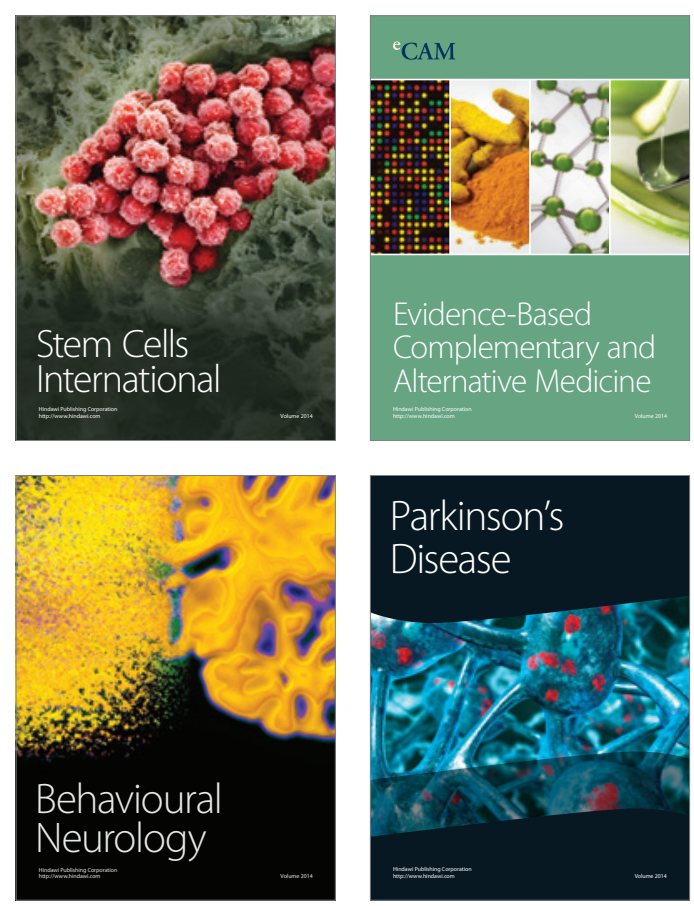

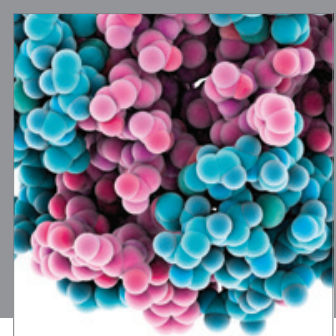

Journal of
Diabetes Research

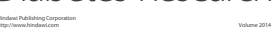

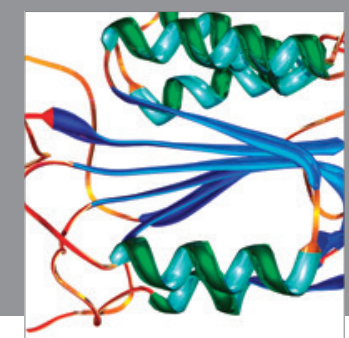

Disease Markers
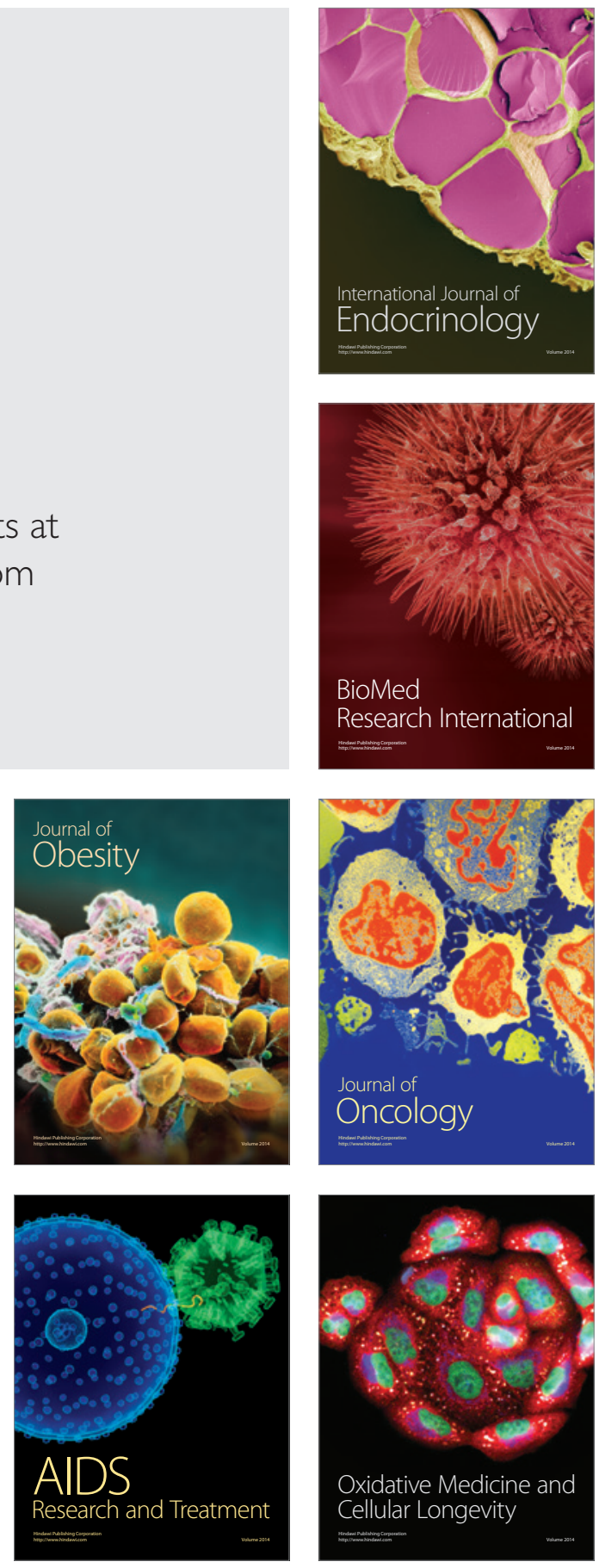